\title{
The Implications of the Departure of the UK for EU Social Policy
}

\author{
Mary Daly, University of Oxford
}

Version accepted for special issue on Brexit of Social Policy and Society, forthcoming 2018

\begin{abstract}
This article considers the significance of the UK departure for EU social policy. To do so it develops and applies a theoretical framework centred upon the economic orientation of policy, its institutional configuration and associated political agency. The analysis first focuses on the role the UK has played since it joined in 1973. Here we see that the UK has consistently viewed and argued for the EU as a market project with a supportive but secondary role for social policy. It can as a consequence claim some success in imprinting its (neo)liberal orientation on EU policy while at the same time securing favourable terms for its own selective engagement with EU policy. The fact that the EU has tolerated and enabled this suggests a far greater degree of flexibility than is customarily assumed and lays out the ground for a multi-speed Europe going forward. The signals regarding EU social policy's future after the UK departs are very mixed. While there are some signs of a more social impulse in policy, the strong ties to a market approach, lack of consensus around the need for a different type of EU social policy engagement and institutional and political hierarchies constrain change.
\end{abstract}

This article examines the departure of the UK from the perspective of its implications for EU social policy. It is both forward-looking in the sense of anticipating the likely change occasioned and also backward looking, surveying the history of the UK's role in supranational social policy. The article suggests that studying the relationship between the UK and EU reveals fundamental insights about both UK and EU social policy. The analytic approach adopted reflects two over-arching features of EU social policy. The first is its complexity, which underlines the need to consider not just policy content or orientation but also how the institutional configuration frames member state sovereignty and affects the associated politics. Secondly, the contested nature of EU social policy is to be emphasised, given that many of the core actors view the EU as a market-making project while for others 'social Europe' is a meaningful vision and goal to aspire to.

The article is organised into three main parts. A first section sets out the analytical framework this is centred around economic orientation, scope and role vis-à-vis member state policy and political agency. The second part focuses on how the UK has engaged with the EU in terms of attempts to influence both the content of policy and the alliances in favour of one policy approach over others. In the third section we consider the changes likely to be set in train by the UK's departure. The latter is in many respects a thought exercise, extrapolating from key developments to date. The argument proffered overall is that the departure of the UK is significant for the nature of EU social policy going forward, as it affects the structure of decision making and may also effect change in the orientations to social policy that win the day at EU level. Of course, a range of factors will play a role and it is impossible to tell for how long the impact of the UK departure will last. While it is beyond the scope of this article to go into these in any detail, a line of analysis is developed around the effect of the UK's leaving in terms of how structural elements - including 
institutional readjustments regarding voting for example - and also politico-ideological differences and contestation constrain significant change.

Before proceeding, a few words are in order to clarify the aim and exercise involved. First it is important to be clear that it is the departure of the UK that is the point of interest. Moreover this is considered in light of how the UK has engaged with EU social policy and the policies and models it has promoted or favoured within the EU context. The article, therefore, has a smaller canvas than either Brexit (which is a much broader political and economic phenomenon than the departure of the $\mathrm{UK}^{1}$ ) or foretelling the future of EU social policy on the basis of a wider range of factors. We should also underline that the article does not seek to explain the Brexit vote in the UK. ${ }^{2}$

Studying EU Social Policy

For the purposes of understanding EU social policy, it is helpful to differentiate between economic orientation, institutional configuration and political agency.

The origins and self-definition of social policy at EU level render economic and market orientation a crucial line of analysis. The original Treaties for the European Economic Community defined and ratified social policy at EU level mainly for the purposes of harmonising employment and living standards across the member states, in the service of creating a common market for goods and services and enabling freedom of movement of workers (Cram 1997). While the remit has been expanded in subsequent treaties, EU social policy is always put through the needle's eye of its impact on market functioning. Developing this insight, Wolfgang Streeck (1995) has constructed an analytic framework that differentiates between social policy that is market making and that which is market correcting. He argues that the economic and market nature of European integration favours the former as the goal is to integrate and improve the efficiency of the EU (labour) market. The types of policies that fit this mould centre around the removal of regulations and barriers to trade and unfettered competition, a model of social policy that is to some extent familiar from the neo-liberal framing (Daly 2012; Copeland and Daly 2018). Market-correcting measures, on the other hand - which are familiar from some social democratic-oriented welfare states but are less common at EU level - aim at ameliorating poor market outcomes and involve redistributive intervention in line with standards of adequate income, social protection and social justice. In a nutshell, the market-making social policy approach conceives of the EU's policy role in terms of negative integration measures that aim at barrier removal, whereas market-correcting policies are conceived as a more positive form of integration as they seek to bring about better social outcomes (Scharpf 1996).

The second analytic element is the role vis-à-vis member state social policy. Readers of this journal hardly need reminding that the territory of the EU encompasses very different types of national social policy models (Carmel and Papadopoulos 2016). Hence, any engagement with social policy on the part of the EU has to recognise that welfare is in Europe a national concept and must therefore countenance varying notions of state, nation, security, responsibility, justice and welfare (Lamping 2010; Geddes 2013: 10). This helps us to appreciate why the Treaties were crafted so as to define and delimit the supranational social policy remit and underpin it with the principle of

\footnotetext{
${ }^{1}$ See Outhwaite (2017) and the special issue of this journal earlier this year (Social Policy \& Society 2018).

${ }^{2}$ See, for example, the special issue of Socio-Economic Review edited by Jacquie O'Reilly in 2016 and the special issue of Journal of Social Policy in 2017.
} 
subsidiarity (whereby the appropriate level of social policy agency is located at member state level) (Leibfried 2015). National borders provide the boundaries of welfare distribution and redistribution in the EU (Lamping 2010). Within such constraints, the overall aim in relation to member state social policy has hovered between integration, harmonisation and co-ordination at its most expansive end and mutual recognition of diversity and cross-national policy learning at the more intergovernmental end. It is only in regard to the social protection rights of EU migrant workers that we have seen the strongly interventionist approach (or EU welfare state). The thrust over time has been for the EU to seek to 'colonise' particular thematic areas of social policy (Daly 2017). The latter include equal treatment, occupational health and welfare and, in the last 20 years or so, employment, poverty and social exclusion and the reform of national systems of health, education and pensions (Anderson 2015). In order to appreciate which fields the EU engages with and the degree of its engagement, the matter of policy-making method is especially important. Here the notion of the EU as a system of multi-level governance is a helpful frame, since it captures both the diversity of methods and the shared nature of competence and decision making (Hooghe and Marks 2001). Hemmed in legally but committed to cooperation among member states in social policy, the EU has overseen the development of a range of methods which are an alternative to law (Trubeck and Trubeck 2005). Among the newer methods are the so-called 'soft methods' which, focusing on issue framing and consensus building, aim to exert influence on member state social policy by voluntaristic means rather than imposition of change through law (Tholoniat 2010). The 'Open Method of Co-ordination' is a key method here, characterised by the EU issuing policy guidelines and enabling mutual learning and emulation. In addition, the rule on unanimous agreement for significant policy change has been relaxed through the application of Qualified Majority Voting (QMV). The most notable social policy fields in which QMV is applied include occupational health and safety, equal treatment, working conditions and the integration of persons excluded from the labour market. These developments have opened a greater space for progress on social policy at EU level but they also underline how progress in market-correcting measures (e.g., social security and social protection) can only be made by constant adaptation and highconsensus political support on the part of a large number of actors (Lamping 2010).

Thirdly, there is the matter of politics and political agency. This plays out at different levels. First, it is shaped by the power dynamics among the EU institutional actors - the Commission, Council, European Court of Justice (ECJ) and Parliament (among the most significant for social policy) (Leibfried 2015). Second, there are the non-institutional actors, especially the member states but also the social partners and NGOs. Since these all in one way or another engage in political agency, they draw on and bring forward particular perspectives and interest positions on social policy. The different ideological orientations towards social policy - familiar from the national level - are given life also through strategic agency among the EU institutional actors. Hence at various periods, different actors favour more or less progressive or expansionist approaches. That said, the social policy ierritory at EU level is generally occupied by the member states, a situation which the institutional and non-institutional actors have to confront when they want to bring about policy change (Lamping 2010). Of course, member states are not always against EU social policy, but the national social policy priorities and the prevailing politics around welfare influence the approach they take to EU developments and the strategies they adopt in that regard.

When do we find when we apply this set of lenses to understand the UK-EU relationship on social policy? 
2. The UK and EU Social Policy: Policy Orientations, Institutions and Politics

Andrew Geddes (20113: 252) has characterised the UK-EU relationship generally as one of conditional and differentiated engagement. Against a popular image of the UK as perennially obstructionist in its EU engagement, it is important to emphasise periods when the UK was a prominent proponent of certain policies at EU level. Note, as evidence, the pivotal role of the UK in the establishment of the European Regional Development Fund in the 1970s, the single market in the 1980s and enlargement in the 1990s and 2000s (McGowan and Phinnemore 2017: 80-81). Successive UK governments were especially sure about what they opposed, and social policy features prominently here. According to Hix et al (2016), over the 50 years or so of its membership, the most striking and consistent position adopted by UK governments in their approach to the EU - in terms of both direct policy engagement and voting patterns on the Council and in the European Parliament - was an ideological opposition to a more social Europe. The three-part framework developed above helps to parse this.

To take the policy orientation first, the UK has tended to promote the type of social policy approach embodied by its own liberal welfare state, that is, in essence a market-making vision. Margaret Thatcher, for example, was a vocal champion of the European single market, seeing its potential benefits for the deregulatory social policy reforms she was pursuing at home in the 1980s (Geddes 2013). This also reflected her wish for the EU to be something more than a free trade area - free enterprise within the constitutional order of EU law was a key part of the Thatcher vision (Chochia et al. 2018: 133). Her allegiance was to a common market rather than the single market that later emerged (which involves much more power for the EU institutions and promotes top-down harmonisation) (ibid). Similarly, Tony Blair valued the market-making dimensions of EU social policy, especially favouring the tighter linking of employment and welfare policies. He cast reform in the frame of deregulatory policies on the one hand and selective social investment on the other (in line with his Third Way approach) (Powell 2000; Carmel and Papadopoulos 2016). Since 2010, and especially in response to the 2008 crisis, we witness another concurrence between the marketmaking orientation of both EU and UK social policy. Successive Conservative-led governments endorsed austerity and strong fiscal policy both at home and in Europe, although in this period the governments adopted a rather semi-detached approach to the EU (Carmel and Papadopoulos 2016). ${ }^{3}$ On the whole, the UK found relatively fertile ground in the EU for an approach that saw the role of social policy as favouring free trade and competition rather than correcting for market failures or weaknesses.

The second element to consider is the approach to the Union as a group of states and the associated institutional parameters. Margaret Thatcher was pro-Europe, but in her own fashion. Thatcher in particular feared the creation of the EU as a political entity, a European state with supranational power and institutions (including a bureaucracy), and favoured therefore a union among states rather than a European union (Chochia et al 2018). She was influenced in this especially by the model of integration presented by the US, and was also especially conscious of Britain's place in the world (Geddes 2013). Thatcher was most comfortable with cooperation in trade and industry

\footnotetext{
${ }^{3}$ It is somewhat ironic to note in this context that the austerity-supporting UK secured an exemption for itself from having sanctions imposed on it through the EU's Stability and Growth Pact (which requires EU governments to hold their deficits to under 3\% of annual gross domestic product and gives the European Commission the power to propose sanctions on governments that do not comply).
} 
(although she also supported a closer relationship on defence policy). Social policy was a major battleground for Thatcher. She voiced strong opposition to an extended EU role in social policy and was one of the main opponents of extending QMV to the social field (Hantrais 2017). Here she feared not just policy content and orientation but consequences for state and economy - the possibility of a heavy burden on small business, the endangering of national sovereignty in the social policy field and greater social and political integration at EU level (ibid). What the British under Margaret Thatcher and later under John Major agreed to was cooperation among member states in the social field rather than integration. In a way, one could say that Tony Blair and Gordon Brown too envisioned the relationship in terms of cooperation, although they were more supportive of political integration. Yet the nation and national interest were ever present for them also. Gordon Brown framed it thus: "we will stand for an approach that is pro-Britain, pro-business and proEuropean single market" (cited in Pond 2010: 256). Both Blair and Brown - and Thatcher before them - tended to use Europe to legitimise and further their own social and employment preferences as against, for example, engaging in a programme of common cause with European leaders (Pond 2010; McGowan and Phinnemore 2017). In particular, the New Labour government - with its hallmark pragmatism - was usually poised to take the credit for the developments under Lisbon while tending to downplay any link to Europe at home (Geddes 2013; Hantrais 2017).

If we turn to the third analytic dimension - political agency and ideology - party political particularities and preferences come to the fore. Of the two major parties in the UK, when looked at over the $40+$ years of membership New Labour was arguably the more ambivalent about the EU. In the first period of EU membership following accession in 1973, the Labour government which assumed power in 1974 when EU membership was a fait accompli-actually called the first UK referendum in 1975 on whether to remain in the EU (67\% voted in favour on a turnout of $65 \%$ ). There was particular dissatisfaction with the terms of accession negotiated by the previous Conservative government led by Ted Heath. ${ }^{4}$ Other roots of the then Labour government's dissatisfaction lay partly in ideology - a fear that EU membership would be a block on socialist industrial policies (which would resurface in Labour's position on the 2016 Brexit referendum) and worries about sovereignty. However once the EU started to develop a more social dimension and become more active on workers' right - as it did especially in the early years of Jacques Delors' presidency of the Commission (1986-1995) - the Labour position became more positive (coinciding with Margaret Thatcher's strong opposition to the EU's social dimension) (Geddes 2013: 84).

One of the strongest examples of UK social policy agency at EU level is its engagement with the Community Charter of Basic Social Rights for Workers (adopted in 1989). The UK played a strongly obstructionist role here under Margaret Thatcher whose stated objections to the Charter were on the grounds that it would lead to over-regulation of the labour market and discourage new job creation (Hantrais 2017: 11). In fact, the UK opted out of the Charter, thereby diminishing its Union-wide legal status to a political declaration. The UK eventually acceded to the Charter, but nearly 10 years later following the election of a new government (New Labour) in May 1997. However, residual ambivalence resurfaced when the Charter of Fundamental Rights (2000) which drew upon the 1989 workers' rights charter - was being negotiated. The position of the New Labour government was one of opposition to its having legal force - again the UK preference was for a proclamation (similar to the Conservative government's position in 1989). However the New

\footnotetext{
${ }^{4}$ This rendered the UK the only net contributor to the European Communities along with Germany at that stage.
} 
Labour government relented on this later and in the end the Charter was integrated into the text of the Lisbon Treaty and hence had legal force (ibid: 16). That said, the UK (along with Poland) did secure a special protocol whereby the social policy requirements are not binding and the application of the Treaty to the UK is delimited specifically so that the ECJ or any court cannot find the national practices inconsistent with Treaty rights. The Pregnant Workers Directive offers another example of how the UK has resisted EU social policy (Guerrina and Masselot 2018). ${ }^{5}$

\section{Implications of the UK's Departure for EU Social Policy}

The balance of evidence can be summarised to suggest two things: the UK has been a very important social policy actor at EU level; it has been an exceptional member state. Throughout, the UK has strategised to negotiate special conditions for itself (Boyer 2016) and it has also managed to imprint its vision of (mainly neo-liberal) policy on EU social policy. The British attempted, and in key respects succeeded, to get the best of both worlds, with the significant achievement that within the EU the UK has had the most optouts and most often been the beneficiary of special treatment. This is, of course, highly revealing about the UK but we suggest that it is equally revealing about the EU. It demonstrates considerable flexibility in the EU political and institutional systems as well as a tolerance of special conditions and of less than whole-hearted participation or adherence to norms and rules by (at least) one country. This is a theme we will come back to in discussions below. There is a social policy specific point here too - the lack of consensus and persistent ambivalence characterising EU social policy and how this can be exploited. This persistent ambivalence is enabled by two characteristic phenomena: the fact that the positions of member states and other actors on EU social policy vary over time and are themselves often inconsistent and, secondly, social policy at EU level is highly politicised. The UK's stance on EU social policy has at times been very welcome in a project biased towards a market-making function.

These insights are very relevant as we look towards the future. But, in facing forward we should heed Boyer's (2016: 839) warning against making determinist predictions and recognise that progress on EU social policy is integrally tied up with major challenges facing the EU. Indeed, 'crisis' has become one of the most popular frameworks for analysing the EU (e.g., Falkner 2016; Dinan et al 2017). The multi-dimensional nature of the current crisis is to be underlined since it includes, as well as Brexit, the Eurozone and migration crises and slow and inefficient decision making, uneven burden sharing and fraying solidarity (Dinan et al 2017). Future development is of course also closely related to national politics, which means that predicting what will happen to EU social policy in the future is akin to predicting who will hold power in the different member states and how that will translate onto power dynamics and ideological orientations at supranational level.

The analytical framework helps to find a way through the complexity, however, underlining that, in the relatively changing and volatile situation which obtains, the future will be shaped by the developing dynamics between policy orientation, institutional closures and opportunities, and emerging politics.

\footnotetext{
${ }^{5}$ Another resistance strategy on the part of the EU has been in less than full implementation of the EU policy measures it signed up to. There are other examples of the UK (and also some other countries but to a generally lesser degree than the UK) not implementing the policies agreed to. See Copeland (2015) on the implementation of the European Employment Strategy and Pond (2010) on the approach adopted to implementing the Lisbon Strategy.
} 
First, the question has to be posed of whether the UK's departure will lead to a significant change in the orientation to social policy at EU level. On the face of it the chances are good given that it removes one of the most fervent opponents of a market-correcting orientation in EU social policy. It may also be that Brexit is read and interpreted as requiring a response that changes the social policy orientation to a more market-correcting approach (in the interests of, inter alia, quelling contagion and better addressing inequalities and poor social outcomes). In addition, a lesson from the past suggests that rejection can lead to more social activity. For example, there are grounds to argue that the rejections of different versions of proposed changes to the Treaties by the Danes in 1992 and the French and Dutch in 2005 influenced the more social Lisbon Strategy (Vanhercke 2012). There is some evidence of a more social move currently: the launch of the Pillar of Social Rights in April 2017 for example (European Commission 2017a) and the proposed directive on a work life balance package for parents and carers, which plans to institutionalise paternity leave, parental leave and carer's leave as well as flexible working hours for parents of children aged up to 12 and carers with dependent relatives (European Commission 2017b). The Pillar was especially supported by centre left governments in Sweden, Italy and Malta. It contains a set of 20 rights and principles in relation to three areas: equal opportunities and access to the labour market, fair working conditions and social protection and inclusion. There are some new areas for EU action in it - for example housing, social protection of the self-employed - it is generally ambitious and has elements of an expansive vision of EU social policy (Rasnača 2017).

But there are counter signs also, so much so that the most accurate characterisation of the situation at this stage is of mixed signals. The European Pillar of Social Rights is a statement of principles (and may or may not lead to significant change in law or policy), is not legally binding and (at this stage anyway) is more of a promise than a binding pledge (ibid). In addition, ambivalence is signalled by the fact that the Commission White Paper on the Future of Europe (European Commission 2017c) which sets out five possible scenarios for the EU by 2025 does not place social policy prominently. Social policy is completely absent from some (the status quo and concentration on the single market scenarios) although it is given more prominence as the scenarios become more expansive. The third scenario, for example, is of a multi-speed EU whereby those member states that wish to achieve more together do so in 'coalitions of the willing' The likely outcome perceived here is of a group of countries going forward with concerted actions that apply only to them - the Eurozone is already a precedent although it is two-speed in nature (and here it should be noted that the Pillar of Social Rights is primarily conceived for Eurozone members although applicable to all member states wishing to be part of it). Some social policy development is foreseen in this scenario in terms of further deepening of co-operation in taxation and social standards. The fourth scenario - doing less more efficiently - is one where member states concentrate on a few areas but aim to address them more quickly and decisively. This, a recognition of roadblocks, essentially involves more deregulation since, among the areas mentioned that could be dropped or de-prioritised, are regional development, public health and elements of employment and social policy not directly related to the functioning of the single market. The final scenario is doing much more together - wherein cooperation between member states goes further than heretofore in all domains. This is a scenario conceived in terms of greater coordination of fiscal, social and taxation matters and where citizens have more rights derived directly from EU law. Taken as a whole, on my reading the document suggests that the 
Commission has accepted the lack of political will for a market-correcting social policy and the possibility of smaller groups of member states proceeding bilaterally.

This brings us to the second set of considerations - the hierarchies and institutional arrangements that prevail. The special concessions to the UK - together with other developments - could be taken to indicate a move to a multi-speed Europe or, put otherwise, differentiated integration (Leruth 2015). The UK has played a leading role regarding opt-outs - being the member state with the most optouts - and in this and other ways it has carved out the path of a slow lane for EU integration (Geddes 2013: 10). The UK has been accompanied in this on occasion by Denmark (which obtained opt-outs from the Maastricht Treaty on Economic and Monetary Union, European Union citizenship, and justice and common defence issues), Poland (from the Charter of Fundamental Rights) and Ireland (from the freedom, security and justice policies). The opt-out clauses - and differentiated integration in general - can be best understood as an institutional and political response to EU enlargement which brought in member states with different priorities and histories and meant that greater diversity has had to be managed (Leruth 2015; Keedus et al 2018). However there has to be some limit on opt-outs and it is especially important that the larger member states opt in (the UK again being the exception) - indeed some of the changes have been led by a Franco-German alliance to counter the UK's obstructionist position on further integration. Other developments that potentially contribute to a multi-speed Europe include the 'enhanced cooperation' institutionalised in the Treaty of Amsterdam in 1997 and the Treaty of Nice in 2003, by which a minimum of nine member states are allowed to engage in advanced cooperation in an area within Union competence even if other member states choose to remain uninvolved. This therefore allows member states - and the Union as a whole - to move at different speeds (ibid). The Treaty of Nice also made the blocking of planned integration measures harder. There are both opportunities and risks in all of this. In regard to the opportunities it may be, as Fossum (2015) suggests, that a future EU may combine all of the following: accelerated integration for some, outright disintegration for others and greater differentiation for the rest. The risks include potential strengthening of the EU's centre leading to divisions between centre and periphery, the undermining of solidarity and the risk that differentiated integration becomes differentiated disintegration (Dinan et al 2017: 372).

If we turn to the politics, it is first helpful to reflect on the power vacuum that will be left by the UK's departure. In terms of the large member states, the UK most frequently allied with Germany in defence of market competition, although the gap between the UK and Germany has been widening in the last decades due to very different positions on integration. The UK, especially in the last decade or so, has also found common cause with some of the Eastern European countries in resisting further expansion of the social orientation of the EU (Mölder 2018). The countries which have voted most frequently with the UK in the European Council are Ireland, Sweden, the Netherlands and Luxembourg (Staal 2016). There is no easy interpretation of this though since the voting alliances varied according to the issue at hand (and the government in power in the particular countries). The recent recession - and reactions to the way it was handled by Brussels is also a conditioning factor on future political alliances. Furthermore, it is not necessarily the social democratic countries that have played a leadership role in expanding EU social policy Sweden and Denmark tend not to support expansion of EU social ambition for example (for a range of reasons but frequently in protection of their own model of social policy which they tend to see as relatively independent of and even superior to that of the EU). It tends to be the 
Mediterranean countries that push for more market-correcting EU social policy, along with Belgium, France and Luxembourg (although to varying degrees at different periods) (Copeland and Daly 2012). The former have been especially hit by the recession and the changed political constellation associated with it (including increased ambivalence if not distrust towards the EU given the austerity-oriented reforms that were forced on some of the countries receiving bail-out assistance). So future initiatives on EU social policy may not be forthcoming from these quarters.

Some national governments have clearly read Brexit as a marker against a too powerful and centralised EU - in reacting to it the Polish and Hungarian governments have called for more powers to be returned to the member states for example. One thing is certain though: that the formula of relative country weightings for QMV will change. Analyses of how a QMV threshold can be reached after Brexit suggest that the large countries will dominate. In particular Kóczy's (2016) game theory analysis suggests that the power of Germany France, Italy and Spain will grow the most (by 15\%) as will that of Poland (7\%), whereas some of the smaller countries (with Cyprus, Estonia, Luxembourg and Malta mentioned) will see a significant decline in power. Brexit also makes it more difficult to muster the necessary $36 \%$ (of the EU population) to block a vote in the Council.

Of course, the outcome will by foretold not by a mathematical probability but by political engagement by the range of EU actors and the opportunities they can exploit and the coalitions and compromises they are prepared or able to engage in. This suggests the conclusion, then, that the future for EU social policy will probably be one of 'muddling through', subject as in the past to continuous rounds of interaction and contestation between a transnational process of rules and rule making and political engagement on the part of member states acting mainly as national political actors. 


\section{References}

Anderson, K. M. (2015) Social Policy in the European Union, London: Palgrave.

Boyer, R. (2016) 'Brexit: the day of reckoning for the neo-functionalist paradigms of the European Union', Socio-economic Review, 14, 4, 836-840.

Carmel, E. and Papadopoulos, T. (2016) 'Deatached, hostile, adaptable and liberalising: The chameleon qualities of the UK's relationship with EU social policy', The Political Quarterly, 87, 2: $228-237$.

Chochia, A, Ramiro Troitiño, D., Kerikmäe, T. and Shumilo, O. (2018) 'Enlargement to the UK, the Referendum, of 1975 and position of Margaret Thatcher', in D. Ramiro Troitiño, T. Kerikmäe, and A. Chochia (eds) Brexit History, Reasoning and Perspectives, Dordrecht: Springer, pp.115139.

Copeland, P. (2015) 'The European Union and the 'social deficit', Representation, 51, 93-106.

Copeland, P. and Daly, M. (2012) 'Varieties of poverty reduction: Inserting the poverty and social exclusion target into Europe 2020’, Journal of European Social Policy, 22, 3: 273-87.

Copeland, P. and Daly, M. (2018) 'The European Semester and EU social policy', Journal of Common Market Studies, Early View.

Cram, L. (1997) Policy-making in the European Union Conceptual Lenses and the Integration Process, London: Routledge.

Daly, M. (2012) 'Paradigms in EU social policy: A critical account of Europe 2020', Transfer, 18, 3: $273-84$.

Daly, M. (2017) 'The dynamics of European Union social policy”, in P. Kennett and N. LendvaiBainton (eds) Handbook of European Social Policy, Cheltenham: 2017, Edward Elgar, pp.93107.

Dinan, D., Nugent, N. and Paterson, W.E. (eds) (2017) The European Union in Crisis, London: Palgrave.

European Commission (2017a) Establishing a European Pillar of Social Rights, COM(2017) 250 final, Brussels: European Commission.

European Commission (2017b) Proposal for a Directive of the European Parliament and of the Council on Work-life Balance for Parents and Carers and Repealing Council Directive 2010/18/EU, COM(2017) 253 final, Brussels; European Commission.

European Commission (2017c) White Paper on the Future of Europe Reflections and Scenarios for the EU27 by 2025, Com(2017) 2025, Brussels: European Commission. 
Falkner, G. (2016) 'The EU's current crisis and its policy effects: Research design and comparative findings', Journal of European Integration, 38, 3: 219-235.

Fossum, J. E. (2015) 'Democracy and differentiation in Europe', Journal of European Public Policy, 22, 6: 799-815.

Geddes, A. (2013) Britain and the European Union, London: Palgrave Macmillan.

Guerrina, R. and Masselot, A. (2018) 'Walking into the footprint of EU Law: Unpacking the gendered consequences of Brexit', Social Policy \& Society, 17, 2: 319-330.

Hantrais, L. (2017) The Social Dimension in EU and UK Policy Development: Shaping the PostBrexit Legacy, London School of Economics Centre for International Studies, Working Paper CIS/2017/04.

Hix, S., Hagemann, S. and Frantescu, D. (2016) Would Brexit Matter? The UK's voting record in the Council and European Parliament, VoteWatch Europe.

Hooghe, L. and Marks, G. (2001), Multi-level Governance and European Integration, Boulder, Col.: Rowman and Littlefield.

Journal of Social Policy, 46, 4, October 2017.

Keedus, L., Chochia, A., Kerikmäe T. and Ramiro Troitiño, D. (2018) 'The British role in the emergence of a multi-speed Europe and enhanced cooperation', in in D. Ramiro Troitiño, T. Kerikmäe, and A. Chochia (eds) Brexit History, Reasoning and Perspectives, Dordrecht: Springer, pp.187-195.

Kóczy, L.A. (2016) How Brexit Affects the EU Power Distribution, Discussion Papers MT-DP 2016/11, Institute for Economics, Centre for Economic and Regional Studies, Hungarian Academy of Sciences,

Lamping W. (2010) 'Mission impossible? Limits and perils of institutionalizing post-national social policy', in M. Ross and Y. Borgmann-Prebil (eds) Promoting Solidarity in the European Union, Oxford: Oxford University Press, pp. 46-72.

Leibfried, S. (2015) 'Social policy: eft to judges and to the markets?', in H. Wallace, M.A. Pollack and A.R. Young (eds), Policy-Making in the European Union, 7th edn, Oxford: Oxford University Press, pp. 263-292.

Leruth, B. (2015) 'Operationalising national preferences on Europe and differentiated integration', Journal of European Public Policy, 22, 6: 816-835. 
McGowan, L. and Phinnemore, D. (2017) 'The UK: membership in crisis', in D. Dinan, N. Nugent and W.E. Patterson (eds) The European Union in Crisis, London: Palgrave, pp. 77-99.

Mölder, H. (2018) 'British approach to the European Union: from Tony Blair to David Cameron', in D. Ramiro Troitiño, T. Kerikmäe, and A. Chochia (eds) Brexit History, Reasoning and Perspectives, Dordrecht: Springer, pp. 153-173.

Nugent, N. (2017) 'The crisis and the EU's institutions, political actors and processes, in D. Dinan, N. Nugent and W.E. Paterson (eds) (2017) The European Union in Crisis, London: Palgrave, pp.167-187.

O'Reilly, J. et al (2016) 'Brexit: understanding the socio-economic origins and consequences', Socio-economic Review, 14, 4, 807-854.

Outhwaite, W. (2017) Brexit: Sociological Responses, London: Anthem Press.

Pond, R. (2010) 'Implementation and impact of the Lisbon Strategy 2000-2010 on employment and social policies in the United Kingdom', in European Parliament (ed.), The Lisbon Strategy 2000-2010: an analysis and evaluation of the methods used and results achieved, Final Report, IP/A/EMPL/ST/ 2008-07, Brussels: Directorate General for Internal Policies, 255-63.

Powell, M. (2000) 'New Labour and the Third Way in the British welfare state: A new and distinctive approach?', Critical Social Policy, 20, 1: 39-60.

Rasnača, Z. (2017) Bridging the Gaps or Falling Short? The European Pillar of Social Rights and What it Can Bring to EU-level Policymaking, Brussels: ETUI Working paper 2017.05.

Scharpf, F. (1996)' Negative and positive integration in the political economy of European welfare states', in G. Marks, F. Scharpf, P.C. Schmitter and W. Streek (eds) Governance in the European Union, London: Sage, pp. 15-39.

Social Policy \& Society (2018) Themed Section on UK's membership of the EU, 17, 2: 259-348.

Staal, K. (2016) Brexit Implications for Influence on EU Decision Making, Presentation at VIVES workshop "The Stability of Regions, Culture and Institutions" at the University of Leuven (Belgium) on June 2nd, 2016.

Streeck, W. (1995) 'Neo-voluntarism: a new European social policy regime'. European Law Journal, 1, 1, 31-59.

Tholoniat, L. (2010) 'The career of the Open Method of Coordination: lessons from a "soft" EU instrument', West European Politics, 33, 1, 93-117.

Trubeck, D. M. and Trubeck, L. G. (2005) 'Hard and soft law in the construction of social Europe: the role of the Open Method of Co-ordination'. European Law Journal, 11, 3, 343-364. 
Vanhercke, B. (2012) Social Policy at EU Level: From the Anti-poverty Programmes to Europe 2020, Background Paper, Brussels: European Social Observatory. 